http://dx.doi.org/10.4314/jae.v16i1.3

\title{
Assessment of the Effects of Climate Change on Livestock Husbandry and Practices in Jigawa State, Nigeria
}

\author{
${ }^{1}$ Bidoli, T. D; ${ }^{2}$ Isa, A. G; ${ }^{1}$ Shehu, B ${ }^{1}$ Kezi ,D. M. and ${ }^{3}$ Abdullahi, M. Y. \\ 1 National Agricultural Extension and Research Liaison Services (NAERLS), \\ A. B. U. Zaria \\ 2 State Universal Basic Education, Dutse. Jigawa State \\ 3 Department of Agric Economics and Extension, Nuhu Bamali Polytechnic, Zaria \\ E-mail: bidolitd@yahoo.com Mobile: 08032846023
}

\begin{abstract}
The investigation of the effects of climate change on livestock husbandry and practices in Jigawa State, Nigeria, was aimed at assessing the level of awareness of climate change by nomads and also determine the effect of climate change on livestock husbandry and practices. Using random sampling method, data were collected from 105 livestock nomads in seven nomadic communities covering seven Local Government Areas (LGAs) of Jigawa State. Data were collected by the use of questionnaire and observation. Data were analyzed by the use of frequency, percentage, and weighted means. About $98 \%$ of nomads understood what was meant by climate change and also $94.3 \%$ observed variations in their environment as a result of climate change. Majority of respondents (76.2\%) observed and experienced the effect of climate change since $5-20$ years ago; while $7.6 \%$ observed and experienced the effects of climate change for over 20 years back. Ranking of effects of climate change on livestock husbandry and practices showed reduced feed intake $\left(1^{\text {st }}\right)$, reduced growth rate $\left(2^{\text {nd }}\right)$, increased frequency of abortion $\left(3^{\text {rd }}\right)$, reduced birth rate $\left(4^{\text {th }}\right)$, increased disease condition $\left(5^{\text {th }}\right)$, increased incidence of parasites $\left(6^{\text {th }}\right)$ and increased mortality rate $\left(7^{\text {th }}\right)$ as major effects. It was recommended that animal production/veterinary services should be stepped up, diversify their production to include crops and other sources of income generation and establish more gazing reserves.
\end{abstract}

Keywords: Assessment, Effect, Climate change, Livestock husbandry, Nigeria 


\section{Introduction}

Livestock subsector is one of the fastest growing agricultural subsectors in developing countries and the growth is driven by the rapidly increasing demand for livestock products. This demand is being stimulated by population growth, urbanization and increasing incomes in developing countries (Delgado, 2005). Livestock production being a major component of agricultural economy of Nigeria accounted for five to six percent of the total Gross Domestic Products (GDP) and between $15 \%$ and $20 \%$ of the GDP of agriculture in 2004 (Agunbiade, 2009). Domestic animals like cattle, sheep, goats, pigs, poultry, and other livestock are integral to rural livelihoods and culture in Nigeria; providing food (meat, blood, eggs and dairy products), materials (wool, hide, horns, etc.), income, and mechanical power for pulling carts or for ploughing fields. Specifically, livestock production sustains the employment and incomes of millions of people in rural areas and generates animal power and organic manure for arable farming mainly in the northern part of the Nigeria (Lamorde, 1998).

Climate change refers to any change in climate overtime, whether due to natural variability or as a result of human activity (IPCC, 2001). While climate change is a global phenomenon, its negative impacts are more severely felt by poor people in developing countries who rely heavily on the natural resource base for their livelihoods. Rural poor communities rely greatly for their survival on agriculture and livestock husbandry that are amongst the most climate-sensitive economic sectors. Climate change will have far-reaching consequences on animal husbandry mainly via impacts on grass and range productivity. Heat stress on animals will reduce the rate of animal feed intake and cause poor performance growth (Rowlinson, 2008). A summary of the direct effects of climate change on livestock husbandry and practices as reported by Smit et. al. 1966 are: (a) the impact of changes in livestock feed-grain availability and price; (b) impacts on livestock pastures and forage crop production and quality; (c) changes in the distribution of livestock diseases and pests; and (d) the direct effects of weather and extreme events on animal health, growth and reproduction. Developing countries will be most impacted because of their lack of resources, knowledge, veterinarians and extension services and research technology development (FAO, 2008). Livestock producers have traditionally adapted to various environmental and climatic changes by building on their in-depth knowledge of the environment in which they live. However, increased human population, urbanization, environmental degradation and increased consumption of animal sourced foods have made some of the coping mechanisms ineffective (Sidahmed, 2008).

In this regard, there appears to be a great decline in livestock production and husbandry being stimulated by impacts of climatic variations on natural resource use among farmers in most parts of Northern Nigeria. Climatic change tends to impact on livestock production systems because environmental conditions can affect the mechanisms and rates of heat gain or loss by all animals as well as induce shortages in available water and grazing areas among other factors. 
An investigation of the effects of climate change on livestock husbandry and practices in Jigawa State, Nigeria, was designed to:

(i) assessing the level of awareness of climate change by livestock nomads and

(ii) determine the effect of climate change on livestock husbandry and practices as perceived by nomads.

\section{Methodology}

The study was conducted in Jigawa State in northern Nigeria which is situated between Latitudes $11^{\circ} \mathrm{N}$ and $13^{\circ} \mathrm{N}$ and Longitudes $8^{\circ} \mathrm{E}$ and $10.15^{\circ} \mathrm{E}$, having a total land area of approximately $22,410 \mathrm{Km}^{2}$ and a population of about 4.3 million. Jigawa state has a tropical climate defined by raining season (May to September) and dry season (October to April). Maximum temperatures of about $40^{\circ} \mathrm{C}$ are recorded between the months of March to September; while lower temperatures of $11^{\circ} \mathrm{C}$ are recorded between October and February. However, the state experiences a substantial temperature variation during these periods. Annual rainfall is between $600 \mathrm{~mm}$ and $1000 \mathrm{~mm}$ with an average of about $650 \mathrm{~mm}$. Most parts of the state lie within the Sudan Savannah although features of Guinea Savannah are observed in the southern parts. Jigawa state has vast fertile arable land that supports the production of almost all tropical crops. The Sudan savannah is made up of vast grazing lands suitable for livestock production. The state is largely characterized by informal sector activities with agriculture as the major economic activity. Over $80 \%$ of the population is engage in subsistence farming and animal husbandry.

Seven (7) Local Government Areas (LGAs) were randomly selected from a total of 27 LGAs in the state (representing about 26\%). One livestock nomadic community was purposively selected from each of the seven LGAs based on high population of livestock nomads. A total of one hundred and five (105) livestock farmers were purposively selected from the seven nomadic communities, from whom primary data was collected through interview method using a structured questionnaire. Data was analyzed by use of frequency, percentage and weighted mean measured by use of a 4-point likert scale of serious, mild, severe and very severe. The scale were assigned 4,3,2,1 point respectively. The points were used to calculate the sum by multiplying number of respondents in each point scale by the point. Mean is calculated by dividing the calculated sum by the number of respondents (responses). Any calculated mean equal to or more than mean of the scale points $2.5(4+3+2+1=10$ divided by $4=2.5)$ is perceived to have an effect of climate change and any mean lower than 2.5 is perceived not to have an effect of climate change. 
TABLE 1

Sampled respondents among selected nomadic communities

\begin{tabular}{llll}
\hline LGA & $\begin{array}{l}\text { Nomadic } \\
\text { Community }\end{array}$ & Population & $\begin{array}{l}\text { Number of } \\
\text { Respondents }\end{array}$ \\
\hline Kiri & Kafuru & 204 & 20 \\
Kasamma & Riniyel & 160 & 16 \\
Ringim & Muni & 125 & 12 \\
Babura & Afarake & 156 & 15 \\
Kafin Hausa & Lukutu & 252 & 25 \\
Garam & Bingamama & 131 & 13 \\
Kaugama & Kefawa & 40 & 4 \\
Gumel & & & $\mathbf{1 0 5}$ \\
Total & $\mathbf{7}$ & $\mathbf{1 0 6 8}$ & \\
\hline
\end{tabular}

Source: Field Survey, 2011

\section{Results and Discussion}

The information in Table 2 indicated the dominance of males $(85.7 \%)$ in the practice of livestock husbandry. This agrees with Adesehinwa, et. al. (2004) who reported $70 \%$ dominance of males in their study on socio-economic characteristics of ruminant livestock farmers. Majority (42.9\%) of pastoralists fall between the ages of $40-59$ years, with a mean age of $40.79 \%$. Most livestock farmers ages has been reported to be between 40-50 years (Ajala and Gefu, 2003; Verbeek, et. al., 2007 ). Only $30.5 \%$ of respondents had secondary education and above, while $62.8 \%$ had below primary level of education. About $57 \%$ of respondents had family size of less than 11 persons, with the mean family size being 10.59 persons. 
TABLE 2

Socio-economic Characteristic of Livestock Farmers $(n=105)$

\begin{tabular}{llll}
\hline Variable & Frequency & Percent $(\%)$ & Mean $(\overline{\boldsymbol{x}})$ \\
\hline Age (Years) & & & \\
$\leq 20$ & 6 & 5.7 & \\
$20-39$ & 40 & 38.1 & 40.79 \\
$40-59$ & 45 & 42.9 & \\
60 and above & 14 & 13.3 & \\
Gender & & & \\
Male & 90 & 85.7 & \\
Female & 15 & 14.3 & \\
Educational Level & & & \\
No Formal Education & 8 & 7.6 & \\
Qur'anic Education & 33 & 31.4 & \\
Adult Education & 25 & 23.8 & \\
Primary Education & 7 & 6.7 & \\
Secondary Education & 19 & 18.1 & \\
Tertiary Education & 13 & 12.4 & \\
& & & \\
Household Size & & & \\
Less than 11 & 60 & 57.1 & \\
$11-20$ & 34 & 32.4 & \\
$21-30$ & 10 & 9.5 & \\
$31-40$ & 1 & 1.0 & \\
\hline Source: Field Survey, 2011 & &
\end{tabular}

Source: Field Survey, 2011

The data in table 3 indicated that more than $50 \%$ of the nomadic livestock farmers keep 20 or less number of cattle, goat, sheep and poultry while less than $7 \%$ of the livestock farmers kept between 41 to 60 numbers of cattle, goats, sheep and poultry. The table also indicated that the farmers only keep about 20 or less of rabbit, horse and donkey. This implies that livestock husbandry and practices among the study population is crucial as a means of sustaining their livelihoods.

\section{TABLE 3}

Status of livestock husbandry practice in Jigawa State $(n=105)$

\begin{tabular}{llllllll}
\hline Number & Cattle & Goat & Sheep & Poultry & Rabbit & Horse & Donkey \\
\hline $1-20$ & $60(57.1)$ & $62(59)$ & $63(60.0)$ & $54(51.4)$ & $10(9.5)$ & $26(24.8)$ & $44(41.9)$ \\
$21-40$ & $16(15.2)$ & $18(17.1)$ & $15(14.3)$ & $25(23.8)$ & 0 & 0 & 0 \\
$41-60$ & $7(6.7)$ & $7(6.7)$ & $6(5.7)$ & $3(2.9)$ & 0 & 0 & 0 \\
Total & $83(79.0)$ & $87(82.9)$ & $84(80.0)$ & $84(78.1)$ & $10(9.5)$ & $26(24.8)$ & $44(41.9)$ \\
\hline
\end{tabular}

Source: Field Survey, 2011; Figures in parenthesis are percentages 


\section{Awareness of Climate Change}

Information in Table 4 reveals that about $98 \%$ of nomads understood what was meant by climate change and also $94.3 \%$ observed variations in their environment as a result of climate change. Majority of respondents $(76.2 \%)$ had observed and experienced the effect of climate change for about 5-20 years ago. Another $7.6 \%$ had observed and experienced the effects of climate change for over 20 years back. Thus it can be concluded that livestock nomads in the study area are aware and understands what is meant by climate change and equally experienced the effects associated with climate change.

TABLE 4

Awareness of Climate Change $(n=105)$

\begin{tabular}{lll}
\hline Awareness & Frequency & $\begin{array}{l}\text { Percentage } \\
(\%)\end{array}$ \\
\hline $\begin{array}{l}\text { Understanding of climate change } \\
\text { Yes }\end{array}$ & 103 & 98.1 \\
No & 2 & 1.9 \\
Observed climatic changes & & \\
Yes & 99 & 94.3 \\
No & 6 & 5.7 \\
Experienced the effect of climate change & & \\
Less than 5 years & 17 & \\
$5-10$ years & 49 & 16.2 \\
$11-15$ years & 18 & 46.7 \\
$16-20$ years & 13 & 17.1 \\
Above 20 years & 8 & 7.4 \\
\hline Sourc: Feld Survey 2011 &
\end{tabular}

Source: Field Survey, 2011

\section{Weather and Environment Changes}

The data in table 5 presents information on reported weather and environmental changes in the study area which includes yearly rainfalls beginning late $(77.1 \%)$ and ending early (92.4\%), increasing yearly temperatures $(88.6 \%)$, decreasing yearly temperatures $(74.3 \%)$, early drying and shortage of pastures $(86.6 \%)$ and early drying of water sources (88.6\%). This indicates that livestock nomads observed and experienced weather and environmental changes with regards to livestock husbandry practice for not less than 5 years back. Tologbonse, et.al. (2010), reported farmers' opinion that climate change did not increase their incomes, neither did it decrease rate of sickness but that it increase rate of sickness/infection and reduces family incomes. It has also been predicted that by 2025, approximately 480 million people in Africa could be living in water-scarce or water stressed areas (Alteri and Koohaftan, 2008). 
TABLE 5

Reported weather /environmental variations due to climate change (105)

\begin{tabular}{lll}
\hline Changes & Frequency & $\begin{array}{l}\text { Percentage } \\
(\%)\end{array}$ \\
\hline Yearly rainfall begin & 24 & 22.9 \\
Early & 81 & 77.1 \\
Late & & \\
Yearly rainfall end & 97 & 92.4 \\
Early & 8 & 7.6 \\
Late & & \\
Increased temperature & 93 & 88.6 \\
Yes & 12 & 11.4 \\
No & & \\
Decreased temperature & 78 & 74.3 \\
Yes & 27 & 25.7 \\
No & & \\
Early dryness of pasture & 91 & 86.6 \\
Yes & 14 & 13.4 \\
No & & \\
Early dryness of water sources & 93 & 88.6 \\
Yes & 12 & 11.4 \\
No & & \\
\hline
\end{tabular}

Source: Field Survey, 2011

\section{Effect of Climate Change on Livestock Husbandry and Practices}

The weighted means (Table 6) shows respondents' perceived effects of climate change on livestock husbandry and practices in order of ranking. Reduced feed intake $(\overline{\mathrm{X}}=3.08)$, reduced growth rate $(\overline{\mathrm{X}}=3.04)$, increased frequency of abortion $(\overline{\mathrm{X}}=2.97)$, reduced birth rate $(\overline{\mathrm{X}}=2.89)$, increased disease condition $(\overline{\mathrm{X}}=2.84)$, increased incidence of parasites $(\overline{\mathrm{X}}=2.58)$, and increased mortality rate $(\overline{\mathrm{X}}=2.51)$. These situations are capable of affecting the performance and production of domestic livestock, thereby threatening food security and exacerbate malnutrition in the study area. Jones and Thornton (2003) predicted climate change related loses to be affecting principally 40 million poor livestock keepers in mixed systems of Latin America and 130 million in those of sub-Saharan Africa by the year 2055. CEEPA (2006) study found that livestock net revenues in Africa are highly sensitive to climate. Also, the influence of climate change on diseases and parasites that affect domestic animals has been reported. For example, incidences of disease, such as bovine respiratory disease, are known to be increasing with climate change (Duff and Gaylean, 2007). 
TABLE 6

\section{Farmers perception of climate change effects on livestock husbandry $(n=105)$}

\begin{tabular}{lll}
\hline Observed effect & Weighted mean $(\overline{\boldsymbol{X}})$ & Ranking \\
\hline Reduced feed intake & 3.08 & $1^{\text {st }}$ \\
Increased feed intake & 0.49 & $12^{\text {th }}$ \\
Reduced growth rate & 3.04 & $2^{\text {nd }}$ \\
Increased growth rate & 0.45 & $13^{\text {th }}$ \\
Reduced birth rate & 2.89 & $4^{\text {th }}$ \\
Increased birth rate & 0.45 & $13^{\text {th }}$ \\
Reduced frequency of abortion & 1.44 & $9^{\text {th }}$ \\
Increased frequency of abortion & 2.97 & $3^{\text {rd }}$ \\
Reduced disease condition & 1.52 & $8^{\text {th }}$ \\
Increased disease condition & 2.84 & $5^{\text {th }}$ \\
Reduced incidence of parasites & 1.25 & $11^{\text {th }}$ \\
Increased incidence of parasites & 2.58 & $6^{\text {th }}$ \\
Reduced mortality rate & 1.40 & $10^{\text {th }}$ \\
Increased mortality rate & 2.51 & $7^{\text {th }}$ \\
\hline
\end{tabular}

Source: Field Survey, 2011

Furthermore, the resultant impact of climate change effects on the livestock nomads' husbandry practices were investigated (Table 7) and these impacts include reduced incomes $(82.5 \%)$, migration with family and stocks $(60.2 \%)$, conflict with other farmers $(64.1 \%)$ and competition over grazing areas $(72.8 \%)$. Thus it can be argued that climate-related environmental stresses affected livestock nomads in study area to a great extent. It has been reported that the distributional effects of climate change are more likely to fall upon women and children, and upon those involved in subsistence agriculture or pastoralists. The effects of environmental degradation and lower agricultural output reduce the availability of animal feed, and the funds available for livestock husbandry (Savage, et al 2008). 
TABLE 7

Impact of climate change effects on livestock nomads $(n=105)$

\begin{tabular}{lll}
\hline Effect & Frequency & Percentage \\
\hline Reduced Income & & \\
Yes & 87 & 82.5 \\
No & 18 & 17.5 \\
Migration with family and livestock & & \\
Yes & 62 & 60.2 \\
No & 41 & 39.8 \\
Conflict with other farmers & & \\
Yes & 66 & 64.1 \\
No & 37 & 35.9 \\
Competition for grazing area & & \\
Yes & & \\
No & 75 & 72.8 \\
& 28 & 27.2 \\
\hline
\end{tabular}

Source: Field Survey, 2011

\section{Conclusion and Recommendations}

The study presented an investigation of the effects of climate change on livestock husbandry and practices in Jigawa State, Nigeria with the aimed of assessing the level of awareness of climate change by livestock nomads and also determine the effect of climate change on livestock husbandry and practices. To this effect, livestock nomads were found to be aware and clearly understand what is meant by climate change. It can also be concluded that the effects of climate change on livestock husbandry and practices reduced livestock feed intake, reduced animal growth rate, increased frequency of abortion, reduced birth rate, increased disease condition, increased incidence of parasites, increased mortality rate, reduces income, increased frequent migration with family and stock, increased competition over grazing facilities and conflict with other farmers.

We therefore recommend the following as strategies for livestock nomads to cope with the effects of climate change as they relate to their livestock husbandry practices.

1. Due to the climate change influences on abortion, feed intake, incidences of disease and parasite, mortality and growth rates of livestock, animal production/veterinary services should be stepped up in order to mitigate against high rate of abortion and incidences of disease/parasite, and equally boost feed intake and animal growth and productivity. 
2. Livestock farmer should be encouraged through extension contact to diversify their production to include crops and other sources of income generation.

3. Establishment of gazing reserves and where already in existence, more should be established in order to reduce pressure due to competition and conflicts related to the use of grazing facilities. This may also reduce the frequent migration of nomads together with their family and stock.

\section{References}

Adesehinwa, A.O.K., Okunola, J.O. and Adewumi, M.K (2004). Socio-economic Characteristics of ruminant livestock farmers and their production constraints in some parts of South-western Nigeria. Livestock Research for Rural Development 16 (8). Retrieved June 30, 2009. http://www.Irrd.org/Irrid16/8/ades16061.htm

Agunbiade, J.A. (2009). Meat from Wheat: animal feed resources in a flux. $52^{\text {nd }}$ Inagural Lecture, Olabisi Onabanjo University, Ago-Iwoye

Ajala, M.K. and Gefu, J.O. (2003). Socio-economic factors influencing small ruminants

management practices in Kaduna State. Moor Journal of Agricultural Research; 4(2), pp. 274-280.

Alteri, M.A. and Koohaftan, P. (2008). Enduring Farms, Climate Change, Smallholder and Traditional Farming Communities. Enviroment and Development series 6. Third World Network.

Centre for Environmental Economics and Policy in Africa (CEEPA). 2006. Climate Change and African Agriculture. Policy Note No. 9, August 2006, CEEPA. www.ceepa.co.za on 7/01/12.

Delgado, C. (2005). Rising demand for meat and milk in developing countries: implications for grasslands-based livestock production. In McGilloway, D. A. (Ed.). Grassland: A global resource. The Netherlands:Wageningen Academic Publishers, pp. 29-39.

Duff, G. and Gaylean, M.L. (2007). Recent advances in management of highly stressed, newly received feedlot cattle. Journal of Animal Science. 85; pp.823-840.

FAO (2008). Climate-related Transboundary Pests and Diseases Including Relevant Aquatic Species. Expert meeting, FAO. February, 2008. 
Intergovernmental Panel on Climate Change (IPCC) (2001). Impact, Adaptation and Vulnerability. Contribution of Working Group II of the Intergovernmental Panel on Climate Change to the Third Assessment Report of IPCC. Cambridge University Press. London.

Jones, P.G. and P.K. Thornton. (2003). The potential impacts of climate change on maize

production in Africa and Latin America in 2055. Global Environmental Change 13; pp.51-59.

Oladele, O. I. (2004). Livestock farmers' awareness, access and benefits of Veterinary Extension Services in Southwestern, Nigeria. Livestock Research for Rural Development, Vol. 16, Art. \#39. Retrieved February 19, 2012, from http://www.Irrd.org//rrd16/6/olad16039.htm

Rowlinson, P. (2008). Adapting Livestock Production Systems to Climate Change - Temperate Zones. Livestock and Global Change conference proceeding. May 2008, Tunisia.

Savage, M.; Dougherty, B.; Hamza, M.; Butterfield, R and Bharwani, S. (2008). Socio-Economic Impacts of Climate Change in Afghanistan. Executive Summary of a Report submitted to the Department of International Development (DFID). Stockholm Environment Institute. DFID CNTR 08 8507.

Sidahmed, A. (2008). Livestock and Climate Change: Coping and Risk Management Strategies for a Sustainable Future. In Livestock and Global Climate Change conference proceeding, May 2008, Tunisia.

Smit, B., Mc Nabb, D. and Smihers, J. (1996). Agricultural adaptation to climatic variation. Climatic change 33, 7-29.

Tologbonse, E.B; Auta,S.J; Bidoli, T.D; Jaliya M.M; Onu, R.O. and Issa, F.O (2010). Farmers Perception of the Effects of Climate Change and Coping Strategies in Three Agro-Ecological Zones of Nigeria. Journal of Agricultural Extension. Publisher, Agricultural Extension Society of Nigeria (AESON), 14 (1); pp.144-156.

Verbeek, E., Kanis, E., Bett, R.C. and Kosgey, I.S. (2007) Socio-economic Factors Influencing Small Ruminant Breeding in Kenya. Livestock Research for Rural Development 19 (6). Retrieved June 30, 2009 from http://www.Irrd.org//rrid19/6. 